\title{
Israel Exhibits a Homogenous Male to Female Ratio at Birth for All Races and Religions \\ V Grech
}

\begin{abstract}
Objective: Male live births occur in excess of female live births and their ratio (M/F) is usually expressed as male divided by total births. The value of $\mathrm{M} / \mathrm{F}$ varies, declining with stress. Israel has been shown to have a relatively stable M/F. This study was carried out in order to ascertain whether there were any racial or religious differences in $\mathrm{M} / \mathrm{F}$ in Israel, and to compare with totals for Europe and North America.

Methods: Annual data for male and female live births was available from the Israel Central Bureau of Statistics for the period 2002-2011. Excel was used for data entry, overall analysis and charting. For race, data was available as Jews and others, and Arabs. For religion, data was available as Jews and Moslems.
\end{abstract}

Results: There were a total of 1523956 live births. Overall M/F was 0.5127 (95\% CI 0.5119 0.5135). There were no significant differences between the races and no significant trends with time. M/F is mid-way between that of Europe and the North American.

Conclusion: The psychological and psychiatric effects of stress in Israel are well documented. However, there was no apparent effect on $\mathrm{M} / \mathrm{F}$ that is manifested as racial or religious differences in $\mathrm{M} / \mathrm{F}$. This could be due to equal levels of stress in all groups or insufficient levels of stress or insufficient births to affect M/F.

Keywords: Birth Rate-trends, infant, Israel, newborn, politics, sex ratio From: Academic Department of Paediatrics, Mater Dei Hospital Medical School, Malta. Correspondence: Professor V Grech, Department of Paediatrics, Mater Dei Hospital, Malta E-mail: victor.e.grech@gov.mt 


\section{INTRODUCTION}

Male live births occur in excess of female live births and their ratio (commonly referred to as $\mathrm{M} / \mathrm{F}$ ) is usually expressed as male divided by total births. The value of $\mathrm{M} / \mathrm{F}$ varies. It has been shown to exhibit broad secular trends (1) and to be sensitive to stress (2) Indeed, all forms of stress have been shown to reduce $\mathrm{M} / \mathrm{F}$ and these include natural calamities $(3,4)$.

Manmade events, such as terrorist attacks, have also been shown to reduce M/F. For example, following the September 11 attacks, M/F was shown to have dropped not only in New York,(5) but also in the entire United States.(6) Short periods of war have also been shown to reduce war(7) as has economic turmoil and uncertainty (8).

Overall, Israel has been shown to have a relatively stable $\mathrm{M} / \mathrm{F}$ with no influence from maternal or paternal age, gravidity or parity over the period 2003-2006 (9). However, a study over a longer period showed a significant decline in M/F from 1950 to 1989 with one outlier year (1981) in temporal relation to the destruction of a nuclear reactor that was still under construction near Baghdad. It was speculated that the spectre of war may have resulted in sufficient stress to cause a dip in $\mathrm{M} / \mathrm{F}$ in this year (10).

Racial differences in $\mathrm{M} / \mathrm{F}$ have also been demonstrated in countries wherein such races coexist (11).This study was carried out in order to ascertain whether there were any racial or religious differences in $\mathrm{M} / \mathrm{F}$ in Israel.

\section{SUBJECTS AND METHODS}

Annual data for male and female live births was available from the website of the Israel Central Bureau of Statistics for the period 2002-2011. Excel was used for data entry, overall analysis and charting. For race, data was available as Jews and others, and Arabs. For religion, data was available as Jews and Moslems. 
The quadratic equations of Fleiss were used for exact calculation of 95\% confidence intervals for ratios (12). Chi tests and chi tests for trends for annual male and female births were used throughout using the Bio-Med-Stat Excel add-in for contingency tables (13). A p value $\leq 0.05$ was taken to represent a statistically significant result.

Overall $\mathrm{M} / \mathrm{F}$ for Israel was also compared to amalgamated data for Europe and for the North American Continent (14).

\section{RESULTS}

There were a total of 1523956 live births for the period 2002-2011. Overall M/F was 0.5127 (95\% CI $0.5119-0.5135)$. Annual $\mathrm{M} / \mathrm{F}$ for the study period overall, and by race and by religion are shown in table 1 . There were no significant differences between races and religions and no significant trends with time.

For Europe, over the period 1950-99, M/F was $0.5142(0.5142-0.5143)$ while for the North American Continent, M/F over the period 1958-97 was $0.5112(0.5111-0.5112) . \mathrm{M} / \mathrm{F}$ for Israel was significantly less than for Europe $(p=0.0002)$ but significantly greater than for the North American Continent $(\mathrm{p}=0.0001)$, as per table 2 .

\section{DISCUSSION}

Manmade stress is known to reduce M/F. This may be due to contracting economies,(15) hotly contested political referenda,(16) and even civil strife(17) that falls short of actual warfare.(7) $\mathrm{M} / \mathrm{F}$ in Israel appears to be mid-way between that of Europe and the North American Continent, with no racial or religious differences within the country and significant time trends over the period studied. 
The psychological effects of stress in Israel [manifesting even in psychosomatic manifestations] (18) along with the outright psychiatric effects have been well documented in this region (19). However, there was no apparent effect on $\mathrm{M} / \mathrm{F}$ that is manifested as racial or religious differences in $\mathrm{M} / \mathrm{F}$. This could be due to one or more of the following reasons:

All individuals may be equally stressed so that there may be no difference in $\mathrm{M} / \mathrm{F}$ outcomes. Another alternative is that the stress levels present are insufficient to affect $\mathrm{M} / \mathrm{F}$. Another possibility is that the number of births available for study is too small to detect $\mathrm{M} / \mathrm{F}$ changes, which may be subtle and require larger numbers of births in order to manifest. 


\section{REFERENCES}

1. Gini C. Sulla probabilita che termini di una serie erratica sieno tutti crescenti (o non decrescenti) ovvero tutti decrescenti (o non crescenti) con applicazioni ai rapporti dei sessi nascite umane in intervalli successivi e alle disposizioni dei sessi nelle fratellanze umane. Metron 1955; 17: 1-41.

2. James WH. The human sex ratio. Part 1: A review of the literature. Hum Biol. 1987; 59: $721-52$.

3. Fukuda M, Fukuda K, Shimizu T, Møller H. Decline in sex ratio at birth after Kobe earthquake. Hum Reprod. 1998; 13: 2321-2.

4. Lyster WR. Altered sex ratio after the London smog of 1952 and the Brisbane flood of 1965. J Obstet Gynaecol Br Commonw. 1974; 81: 626-31.

5. Catalano R, Bruckner T, Marks AR, Eskenazi B. Exogenous shocks to the human sex ratio: the case of September 11, 2001 in New York City. Hum Reprod. 2006; 21: $3127-$ 31.

6. Bruckner TA, Catalano R, Ahern J. Male fetal loss in the U.S. following the terrorist attacks of September 11, 2001. BMC Public Health. 2010; 10: 273.

7. Zorn B, Sucur V, Stare J, Meden-Vrtovec H. Decline in sex ratio at birth after 10-day war in Slovenia: brief communication. Hum Reprod. 2002; 17: 3173-7.

8. Catalano RA. Sex ratios in the two Germanies: a test of the economic stress hypothesis. Hum Reprod. 2003; 18: 1972-5.

9. Ein-Mor E, Mankuta D, Hochner-Celnikier D, Hurwitz A, Haimov-Kochman R. Sex ratio is remarkably constant. Fertil Steril. 2010; 93: 1961-5.

10. Grech V. The effect of warfare on the secular trends in sex ratios at birth in Israel, Egypt, and Kuwait over the past 60 years. Libyan J Med. 2014; 9: 23448. 
11. Grech V. State and Regional Differences in the Male-to-Female Ratio at Birth in the United States, 1995-2012. West Indian Med J. 2015 May 15. doi: 10.7727/wimj.2014.284. [Epub ahead of print].

12. Fleiss JL. Statistical methods for rates and proportions. New York: John Wiley and Sons; 1981: 14-15 (2nd edition).

13. Slezák P. Microsoft Excel add-in for the statistical analysis of contingency tables. Int J Innovation Educ Res 2014; 2: 90-100.

14. Grech V, Savona-Ventura C, Vassallo-Agius P. Unexplained differences in the sex ratio at birth in Europe and North America. BMJ 2002; 324: 1010-11.

15. Catalano RA. Sex ratios in the two Germanies: a test of the economic stress hypothesis. Hum Reprod. 2003; 18: 1972-5.

16. Grech V. The male:female ratio at birth was depressed in Québec by the sovereignty referendums. J Obstet Gynaecol Can 2015; 37: 405-11.

17. Grech V. Population stress, civil unrest and the male to female ratio at birth in Chile, Argentina, Australia and Finland. Int J Tropical Dis Health 2015; 6: 27-34.

18. Ablin JN, Cohen H, Clauw DJ, Shalev R, Ablin E, Neumann L, Sarzi-Puttini P, Buskila D. A tale of two cities - the effect of low intensity conflict on prevalence and characteristics of musculoskeletal pain and somatic symptoms associated with chronic stress. Clin Exp Rheumatol. 2010; 28: S15-21.

19. Slone M, Shoshani A. Psychiatric effects of protracted conflict and political life events exposure among adolescents in Israel: 1998-2011. J Trauma Stress 2014; 27: 353-60. 
Table 1: M/F overall and by race and by religion, 2002-2011

\begin{tabular}{crrrrrrrrrrr}
\hline All & $\mathbf{2 0 0 2}$ & $\mathbf{2 0 0 3}$ & $\mathbf{2 0 0 4}$ & $\mathbf{2 0 0 5}$ & $\mathbf{2 0 0 6}$ & $\mathbf{2 0 0 7}$ & $\mathbf{2 0 0 8}$ & $\mathbf{2 0 0 9}$ & $\mathbf{2 0 1 0}$ & $\mathbf{2 0 1 1}$ & Total \\
\hline M & 71318 & 74272 & 74694 & 73956 & 76078 & 77830 & 80254 & 82398 & 85415 & 85162 & 781377 \\
F & 68217 & 70664 & 70513 & 69957 & 72092 & 73849 & 76669 & 78644 & 80840 & 81134 & 742579 \\
Total & 139535 & 144936 & 145207 & 143913 & 148170 & 151679 & 156923 & 161042 & 166255 & 166296 & 1523956 \\
UCI & 0.5137 & 0.5150 & 0.5170 & 0.5165 & 0.5160 & 0.5156 & 0.5139 & 0.5141 & 0.5162 & 0.5145 & 0.5135 \\
$\mathbf{M} / \mathbf{F}$ & 0.5111 & 0.5124 & 0.5144 & 0.5139 & 0.5135 & 0.5131 & 0.5114 & 0.5117 & 0.5138 & 0.5121 & 0.5127 \\
$\mathbf{L C I}$ & 0.5085 & 0.5099 & 0.5118 & 0.5113 & 0.5109 & 0.5106 & 0.5089 & 0.5092 & 0.5114 & 0.5097 & 0.5119
\end{tabular}

Jews and

$\begin{array}{crrrrrrrrrrr}\text { others } & \mathbf{2 0 0 2} & \mathbf{2 0 0 3} & \mathbf{2 0 0 4} & \mathbf{2 0 0 5} & \mathbf{2 0 0 6} & \mathbf{2 0 0 7} & \mathbf{2 0 0 8} & \mathbf{2 0 0 9} & \mathbf{2 0 1 0} & \mathbf{2 0 1 1} & \text { Total } \\ \text { M } & 50480 & 53220 & 53554 & 54062 & 56136 & 57697 & 60018 & 62158 & 64572 & 64626 & 576523 \\ \text { F } & 48124 & 50379 & 50803 & 51050 & 53052 & 54846 & 57455 & 59085 & 60933 & 61924 & 547651 \\ \text { Total } & 98604 & 103599 & 104357 & 105112 & 109188 & 112543 & 117473 & 121243 & 125505 & 126550 & 1124174 \\ \text { UCI } & 0.5151 & 0.5168 & 0.5162 & 0.5174 & 0.5171 & 0.5156 & 0.5138 & 0.5155 & 0.5173 & 0.5134 & 0.5138 \\ \text { M/F } & 0.5119 & 0.5137 & 0.5132 & 0.5143 & 0.5141 & 0.5127 & 0.5109 & 0.5127 & 0.5145 & 0.5107 & 0.5128 \\ \text { LCI } & 0.5088 & 0.5107 & 0.5101 & 0.5113 & 0.5112 & 0.5097 & 0.5080 & 0.5099 & 0.5117 & 0.5079 & 0.5119\end{array}$




$\begin{array}{crrrrrrrrrrr}\text { Arabs } & \mathbf{2 0 0 2} & \mathbf{2 0 0 3} & \mathbf{2 0 0 4} & \mathbf{2 0 0 5} & \mathbf{2 0 0 6} & \mathbf{2 0 0 7} & \mathbf{2 0 0 8} & \mathbf{2 0 0 9} & \mathbf{2 0 1 0} & \mathbf{2 0 1 1} & \text { Total } \\ \text { M } & 20838 & 21052 & 21140 & 19894 & 19942 & 20133 & 20236 & 20240 & 20843 & 20536 & 204854 \\ \text { F } & 20093 & 20285 & 19710 & 18907 & 19040 & 19003 & 19214 & 19559 & 19907 & 19210 & 194928 \\ \text { Total } & 40931 & 41337 & 40850 & 38801 & 38982 & 39136 & 39450 & 39799 & 40750 & 39746 & 399782 \\ \text { UCI } & 0.5140 & 0.5141 & 0.5224 & 0.5177 & 0.5165 & 0.5194 & 0.5179 & 0.5135 & 0.5163 & 0.5216 & 0.5140 \\ \text { M/F } & 0.5091 & 0.5093 & 0.5175 & 0.5127 & 0.5116 & 0.5144 & 0.5130 & 0.5086 & 0.5115 & 0.5167 & 0.5124 \\ \text { LCI } & 0.5042 & 0.5044 & 0.5126 & 0.5077 & 0.5066 & 0.5095 & 0.5080 & 0.5036 & 0.5066 & 0.5118 & 0.5109 \\ \text { Jews } & \mathbf{2 0 0 2} & \mathbf{2 0 0 3} & \mathbf{2 0 0 4} & \mathbf{2 0 0 5} & \mathbf{2 0 0 6} & \mathbf{2 0 0 7} & \mathbf{2 0 0 8} & \mathbf{2 0 0 9} & \mathbf{2 0 1 0} & \mathbf{2 0 1 1} & \text { Total } \\ \text { M } & 48365 & 50915 & 51319 & 51742 & 53729 & 55377 & 57600 & 59764 & 62085 & 62051 & 552947 \\ \text { F } & 45962 & 48212 & 48743 & 48915 & 50784 & 52609 & 55203 & 56835 & 58588 & 59469 & 525320 \\ \text { Total } & 94327 & 99127 & 100062 & 100657 & 104513 & 107986 & 112803 & 116599 & 120673 & 121520 & 1078267 \\ \text { UCI } & 0.5159 & 0.5167 & 0.5160 & 0.5171 & 0.5171 & 0.5158 & 0.5135 & 0.5154 & 0.5173 & 0.5134 & 0.5138 \\ \text { M/F } & 0.5127 & 0.5136 & 0.5129 & 0.5140 & 0.5141 & 0.5128 & 0.5106 & 0.5126 & 0.5145 & 0.5106 & 0.5128 \\ \text { LCI } & 0.5095 & 0.5105 & 0.5098 & 0.5109 & 0.5111 & 0.5098 & 0.5077 & 0.5097 & 0.5117 & 0.5078 & 0.5119 \\ \text { Moslems } & \mathbf{2 0 0 2} & \mathbf{2 0 0 3} & \mathbf{2 0 0 4} & \mathbf{2 0 0 5} & \mathbf{2 0 0 6} & \mathbf{2 0 0 7} & \mathbf{2 0 0 8} & \mathbf{2 0 0 9} & \mathbf{2 0 1 0} & \mathbf{2 0 1 1} & \text { Total } \\ \text { M } & 18439 & 18588 & 18683 & 17579 & 17560 & 17796 & 17857 & 17868 & 18481 & 18207 & 181058\end{array}$




\begin{tabular}{ccccccccccccc} 
F & 17760 & 17841 & 17555 & 16638 & 16777 & 16776 & 17003 & 17385 & 17740 & 17040 & 172515 \\
Total & 36199 & 36429 & 36238 & 34217 & 34337 & 34572 & 34860 & 35253 & 36221 & 35247 & 353573 \\
UCI & 0.5145 & 0.5154 & 0.5207 & 0.5191 & 0.5167 & 0.5200 & 0.5175 & 0.5121 & 0.5154 & 0.5218 & 0.5137 \\
M/F & 0.5094 & 0.5103 & 0.5156 & 0.5138 & 0.5114 & 0.5148 & 0.5122 & 0.5069 & 0.5102 & 0.5166 & 0.5121 \\
LCI & 0.5042 & 0.5051 & 0.5104 & 0.5084 & 0.5061 & 0.5095 & 0.5070 & 0.5016 & 0.5051 & 0.5113 & 0.5104 \\
& & & & & & & & & & & & \\
\hline
\end{tabular}

UCI: Upper 95\% confidence interval; LCI: Lower 95\% confidence interval. 
Table 2: A comparison of M/F for Israel vs. amalgamated data for Europe and the North American Continent.

\begin{tabular}{crrr}
\hline & \multicolumn{1}{c}{ Europe } & \multicolumn{1}{l}{ Israel } & North America \\
\hline Years & $1950-99$ & $2002-11$ & $1958-97$ \\
$\mathbf{M}$ & 159194981 & 781377 & 127034732 \\
$\mathbf{F}$ & 150384968 & 742579 & 121488464 \\
Total & 309579949 & 1523956 & 248523196 \\
UCI & 0.5143 & 0.5135 & 0.5112 \\
M/F & 0.5142 & 0.5127 & 0.5112 \\
LCI & 0.5142 & 0.5119 & 0.5111 \\
chi & 13.7 & & 15.0 \\
$\mathbf{p}$ & 0.0002 & & 0.0001 \\
\hline
\end{tabular}

